Ilmu Pertanian (Agricultural Science)

Vol. 2 No. 2 August, 2017 : 079-084

Available online at http://journal.ugm.ac.id/jip

DOI: doi.org/10.22146/ipas.25903

\title{
Root Morphologycal Responses of Oil Palm (Elaeis guineensis Jacq.) Hybrids to Copper Toxicity
}

\author{
Dwi Nur Shinta Febriani*, Eka Tarwaca Susila Putra, Tohari \\ Department of Agronomy, Faculty of Agriculture, Universitas Gadjah Mada \\ Jln. Flora no. 1, Bulaksumur, Sleman, Yogyakarta 5528, Indonesia \\ *Corresponding email: shinta10438@gmail.com
}

Received: $13^{\text {rd }}$ June 2017 ; Revised: $30^{\text {th }}$ August 2017 ; Accepted: $30^{\text {th }}$ August 2017

\begin{abstract}
The experiment aimed to identify the root response of eight oil palm hybrids to copper toxicity. The factorial treatments were arranged in Randomized Completely Block Design with three blocks as replication. The first factor was the copper toxicity, while eight oil palm hybrids (DxP) consisted of Yangabi (P1), Avros (P2), Langkat (P3), PPKS 239 (P4), Simalungun (P5), PPKS 718 (P6), PPKS 540 (P7), and Dumpy (P8) as second factor. Root growth variables were observed, including total root length, total root area, root volume and diameter, copper content on root, fractal dimension, relative root water content, fresh root weight, and root dry weight. Data were analysed using analysis of variance (ANOVA) and continued with Duncan's Multiple Range Test at $\alpha=5 \%$. There was a declinning in total root length, volume and diameter, fresh and dry weight as the copper content rose on the root tissue, but no significant different was found in total root area.
\end{abstract}

Keywords: Copper Toxicity, Oil Palm, Root

\section{INTRODUCTION}

Copper $(\mathrm{Cu})$ is a micro essential for plant. $\mathrm{Cu}$ has a vital function in electron transport in photosynthesis, as well in respiration and as a cofactor in various enzymies, such as superoxide dismutase, cytokrom c, oxidase, and plastocyanin (Clemens, 2001). $\mathrm{Cu}$ is mostly found in chloroplast $(>50 \%)$ and is bound to plastocyanin (Marschner, 1995). Cu has a high afinity to dioxygen molecules, which explains how $\mathrm{Cu}$ is a metal catalyst of many oxidation reactions. This main group member is mitochondria cytocrome oxidase as the main catalyst of terminal oxidation. $\mathrm{Cu}$ is also found at electrone protein carrier such as plastosianin (Pilon et al., 2006).

Naturally, $\mathrm{Cu}$ is in the range 2 to $100 \mathrm{ppm}$ in soil with the average of about $30 \mathrm{ppm}$. In many plants, $\mathrm{Cu}$ content is about $8-20 \mathrm{ppm}$. Without an adequate $\mathrm{Cu}$ supply, plants growth will decline. Otherwise, an excessive amount of $\mathrm{Cu}$ in soil can cause toxicity on plant. The sources of soil toxicity are from human activity, such as mining, industrial waste, agriculture (fungicide, etc) (Gardner et al., 1985; Mioto et al., 2014). Excessive amount of $\mathrm{Cu}$ can cause structural anatomical, morfological, and physiologycal changes, such as damaging root tissue, declining photosontetic rate and growth (Lequeux et al., 2010). The high consentration of $\mathrm{Cu}$ will first inhibit root growth, then shoot growth. This is not because root is more sensitive in high $\mathrm{Cu}$ concentration, but plant localised copper in root and inhibit the translocation to the shoot (Broadley et al., 2012).

In high $\mathrm{Cu}$ level, $60 \%$ total $\mathrm{Cu}$ in root can be bound to cell wall and plasma membrane of cell wall fraction. Additionaly, $\mathrm{Cu}$ mobility process in root or $\mathrm{Cu}$ absorption reduction through extracellular bond with rooting exudate in some $\mathrm{Cu}$ tolerance mechanisms (Yruela, 2009).

In the vine (Vitis labrusca L.) seedling, root planted in the soil with excessive $\mathrm{Cu}$ without liming shows obvious toxicity symtomps, such as shortening of the differential root cell area, declining size of root apex, larger root diameter, cortex area, cortical cell area, and silindrical area of vascular tissue, then the increasing of total cell that has fenolic content (Ambrosini et al., 2015).

$\mathrm{Cu}$ toxicity symtomps shown in some of root area among others are on apex area, the changing structure of wall cell and tissues, root shortening and thickening, 
increasing of total lateral root, and plasmolysis on epidermis cell which can decreasing the root density (Chen et al., 2013; Juang et al., 2014). This experiment aimed to figure out oil palm root response from eight different hybrids (DxP) Yangabi (P1), Avros (P2), Langkat (P3), PPKS 239 (P4), Simalungun (P5), PPKS 718 (P6), PPKS 540 (P7), and Dumpy (P8) to copper toxicity

\section{MATERIALS AND METHODS}

This experiment had been conducted on November 2014 to Mei 2015 at Bendosari, Madurejo, Prambanan, Sleman and Plant Science Laboratory, Agriculture Faculty of Gadjah Mada University, Yogyakarta.

The experiment held at main nursery level (9 months after planting) from November 2014 to Mei 2015, within 8 different oil palm hybrids (Yangabi (P1), Avros (P2), Langkat (P3), PPKS 239 (P4) Simalungun (P5), PPKS 718 (P6), PPKS 540 (P7) and Dumpy (P8)) and with treatment of toxicity (first with $300 \mathrm{ppm} \mathrm{Cu}$ toxicity from $\mathrm{CuSO}_{4} .5 \mathrm{H}_{2} \mathrm{O}$ by irigation and with no copper adding as a control treatment). The aplication of $\mathrm{CuSO}_{4} .5 \mathrm{H}_{2} \mathrm{O}$ was given from the $37^{\text {th }}$ weeks after replanting on main nursery stage. On the $38^{\text {th }}$ and $48^{\text {th }}$ week after replanting on the main nursery stage, sample plants were taken to the laboratory to measure the total root length and area, root diameter and volume, fractal dimension, relative root water content, $\mathrm{Cu}$ content, root and shoot biomass, plant height, total leaves, root response to $\mathrm{Cu}$ toxicity. Data were analysed using analysis of variance (ANOVA) and followed with Duncan's Multiple Range Test at 5\% alpha.

\section{RESULT AND DISCUSSION}

The additions of $\mathrm{Cu}$ to the plant media significantly increased the $\mathrm{Cu}$ content and absorption on root of Elaeis guineensis Jacq. at main nursery stages (Table 1). In control plants, the $\mathrm{Cu}$ content and absorption were still in normal level. There was not any significant difference among eight Elaeis guineensis Jacq. hybrids. According to Mocquot et al. (1996), Cu toxic critical value in plant was $26 \mathrm{mg} \mathrm{Cu}$ per dry weight on root and $21 \mathrm{mg} \mathrm{Cu}$ per dry weight on leaf. In this research, $\mathrm{Cu}$ in root with $\mathrm{Cu}$ treatment was up to $18.86 \mathrm{mg}$ per root dry weight, which was still in the range under critical value on plant, eventhough the concentration of $\mathrm{Cu}$ on root was much higher in plant with $\mathrm{Cu}$ treatment than control.

The increasing $\mathrm{Cu}$ level on root tissues caused by the adding of $300 \mathrm{ppm} \mathrm{Cu}$ on the media caused some structural damages to the root tissue as the ROS activity increased. Excessive $\mathrm{Cu}$ in root tissue could generate reactive oxygen species (ROS), including $\mathrm{O}_{2}^{-}, \mathrm{H}_{2} \mathrm{O}_{2}$, and the $\mathrm{HO}^{-}$radical, which caused lipid peroxidation and might caused membrane permeability damage (Andrade et al., 2010) led to ion leakage (De Vos et al., 1991), and also disrupt the activity of membrane-bound enzymes (Del Rio et al., 2006). Cell membrane was the primary site of $\mathrm{Cu}$ toxicity as proven by the increased lipid peroxidation (Fidalgo et al., 2013).

Table 1. $\mathrm{Cu}$ content and absorption on oil palm (Elaeis guineensis Jacq.) root at 48 week after replanting at main nursery stage

\begin{tabular}{|c|c|c|}
\hline Treatment & $\begin{array}{c}\mathrm{Cu} \text { Content on Root Tissue } \\
(\mathrm{ppm})\end{array}$ & $\begin{array}{l}\text { Cu Absorption on Root } \\
\text { (mg/Root Dry Weight) }\end{array}$ \\
\hline \multicolumn{3}{|c|}{$\mathrm{Cu}$ Treatment (ppm) } \\
\hline 0 & $23.41 \mathrm{~b}$ & $0.69 \mathrm{~b}$ \\
\hline 300 & $1395.08 \mathrm{a}$ & $18.86 \mathrm{a}$ \\
\hline \multicolumn{3}{|l|}{ Oil Palm Hybrids } \\
\hline Yangambi & $991.28 \mathrm{a}$ & $14.34 \mathrm{a}$ \\
\hline Avros & $538.96 \mathrm{a}$ & $8.55 \mathrm{a}$ \\
\hline Langkat & $710.62 \mathrm{a}$ & $10.15 \mathrm{a}$ \\
\hline PPKS 239 & $733.97 \mathrm{a}$ & $8.65 \mathrm{a}$ \\
\hline Simalungun & $822.58 \mathrm{a}$ & $9.64 \mathrm{a}$ \\
\hline PPKS 718 & $457.90 \mathrm{a}$ & $4.50 \mathrm{a}$ \\
\hline PPKS 540 & $530.10 \mathrm{a}$ & $7.22 \mathrm{a}$ \\
\hline Dumpy & $888.55 \mathrm{a}$ & $15.14 \mathrm{a}$ \\
\hline Interaction & $(-)$ & $(-)$ \\
\hline$\overline{C V(\%)}$ & 25.62 & 16.09 \\
\hline
\end{tabular}


Table 2. Relative root water content on 38 and 48 week after replanting on main nursery stage

\begin{tabular}{|c|c|c|}
\hline \multirow{2}{*}{ Treatment } & \multicolumn{2}{|c|}{ Relative Root Water Content (\%) } \\
\hline & 38 & 48 \\
\hline \multicolumn{3}{|l|}{$\mathrm{Cu}$ Treatment (ppm) } \\
\hline 0 & $36.89 \mathrm{a}$ & $46.00 \mathrm{a}$ \\
\hline 300 & $38.36 \mathrm{a}$ & $32.42 \mathrm{~b}$ \\
\hline \multicolumn{3}{|l|}{ Oil Palm Hybrids } \\
\hline Yangambi & $47.69 \mathrm{a}$ & $37.98 \mathrm{a}$ \\
\hline Avros & $31.93 \mathrm{a}$ & $41.09 \mathrm{a}$ \\
\hline Langkat & $42.38 \mathrm{a}$ & $44.34 \mathrm{a}$ \\
\hline PPKS 239 & $40.39 \mathrm{a}$ & $36.24 \mathrm{a}$ \\
\hline Simalungun & $36.90 \mathrm{a}$ & $34.62 \mathrm{a}$ \\
\hline PPKS 718 & $40.30 \mathrm{a}$ & $37.24 \mathrm{a}$ \\
\hline PPKS 540 & $38.17 \mathrm{a}$ & $39.04 \mathrm{a}$ \\
\hline Dumpy & $23.28 \mathrm{a}$ & $43.11 \mathrm{a}$ \\
\hline Interaction & $(-)$ & $(-)$ \\
\hline$\overline{C V}(\%)$ & 24.67 & 39.37 \\
\hline
\end{tabular}

Table 3. Responses of the oil palm hybrids to $\mathrm{Cu}$ toxicity on root growth at 48 weeks after replanting

\begin{tabular}{lccccc}
\hline \multirow{2}{*}{ Oil Palm Hybrids } & \multicolumn{5}{c}{$\Delta$ Responses on Root Growth (\%) } \\
\cline { 2 - 6 } & $\begin{array}{c}\text { Root } \\
\text { Length }\end{array}$ & $\begin{array}{c}\text { Root } \\
\text { Area }\end{array}$ & $\begin{array}{c}\text { Root } \\
\text { Diameter }\end{array}$ & $\begin{array}{c}\text { Root } \\
\text { Volume }\end{array}$ & $\begin{array}{c}\text { Fractal } \\
\text { Dimension }\end{array}$ \\
\hline Yangambi & $40.23 \mathrm{a}$ & $35.20 \mathrm{a}$ & $1.64 \mathrm{ab}$ & $34.74 \mathrm{a}$ & $-7.22 \mathrm{a}$ \\
Avros & $-908.45 \mathrm{a}$ & $-192.20 \mathrm{a}$ & $41.43 \mathrm{a}$ & $44.43 \mathrm{a}$ & $-0.53 \mathrm{a}$ \\
Langkat & $39.11 \mathrm{a}$ & $44.66 \mathrm{a}$ & $10.12 \mathrm{ab}$ & $45.56 \mathrm{a}$ & $-2.10 \mathrm{a}$ \\
PPKS 239 & $48.15 \mathrm{a}$ & $54.11 \mathrm{a}$ & $5.21 \mathrm{ab}$ & $58.00 \mathrm{a}$ & $-2.38 \mathrm{a}$ \\
Simalungun & $-7.56 \mathrm{a}$ & $25.72 \mathrm{a}$ & $19.01 \mathrm{ab}$ & $17.85 \mathrm{a}$ & $-2.67 \mathrm{a}$ \\
PPKS 718 & $-76.09 \mathrm{a}$ & $-22.45 \mathrm{a}$ & $18.36 \mathrm{ab}$ & $45.27 \mathrm{a}$ & $-4.46 \mathrm{a}$ \\
PPKS 540 & $-26.03 \mathrm{a}$ & $7.04 \mathrm{a}$ & $19.94 \mathrm{ab}$ & $27.90 \mathrm{a}$ & $-1.62 \mathrm{a}$ \\
Dumpy & $27.56 \mathrm{a}$ & $12.05 \mathrm{a}$ & $-25.25 \mathrm{~b}$ & $36.36 \mathrm{a}$ & $-0.86 \mathrm{a}$ \\
\hline Average & -107.885 & -4.84 & 11.31 & 38.78 & 51.37 \\
\hline CV(\%) & 24.429 & 29.828 & 18.933 & 27.933 & 15.011 \\
\hline Remarks: The means in one column followed by the same letter were not significantly different
\end{tabular}

$\mathrm{Cu}$ toxicity might also result from the strong interactions of $\mathrm{Cu}$ with sulfhydryl groups of enzymes and protein in the apoplast of root cell, which could inhibit enzyme activities or caused changes in the structure and replacement of key elements, resulting in deficiency of other nutrients (Yruela, 2005; Kabala et al., 2008). This could affect nutritional status of the plant. In some studies, excessive $\mathrm{Cu}$ could lead to Fe deficiency (Marschner, 1995). It could also lead to nutritional imbalanced which inhibited plant growth and biomass production. It was obviously seen from the declining of shoot and root, both in fresh and dry biomass.

Relative root water content decreased by the $\mathrm{Cu}$ stress treatment at 48 weeks after replanting on main nursery stage observation, but there was no significantly difference in oil palm hybrids (Table 2). In excess of $\mathrm{Cu}$, root tissue lowered its availability of root permeability as a mechanism to inhibit $\mathrm{Cu}$ ion entered the root tissue by lignification in the membrane cell of some tissues. In fact, $\mathrm{Cu}$ was one of the cofactors in lignin synthesise. The increasing of $\mathrm{Cu}$ level in root tissues was followed by the rising of lignification.

Lignin, comprising of phenolic hetero polymers, was a complex component of cell wall (Lin et al., 2005). The adding of nano-CuO on Glycine max at $100,200,400$, and $500 \mathrm{mg} / \mathrm{L}$ enhanced the lignification of root cells, thereby affecting the root development 
Table 2. Relative root water content on 38 and 48 week after replanting on main nursery stage

\begin{tabular}{lcc}
\hline \multirow{2}{*}{ Treatment } & \multicolumn{2}{c}{ Relative Root Water Content (\%) } \\
\cline { 2 - 3 } \multicolumn{1}{c}{300} & 38 & 48 \\
\hline Cu Treatment $(\mathrm{ppm})$ & $38.36 \mathrm{a}$ & $46.00 \mathrm{a}$ \\
\hline \multicolumn{1}{c}{0} & $32.42 \mathrm{~b}$ \\
\hline Oil Palm Hybrids & $47.69 \mathrm{a}$ & $37.98 \mathrm{a}$ \\
Yangambi & $31.93 \mathrm{a}$ & $41.09 \mathrm{a}$ \\
Avros & $42.38 \mathrm{a}$ & $44.34 \mathrm{a}$ \\
Langkat & $40.39 \mathrm{a}$ & $36.24 \mathrm{a}$ \\
PPKS 239 & $36.90 \mathrm{a}$ & $34.62 \mathrm{a}$ \\
Simalungun & $40.30 \mathrm{a}$ & $37.24 \mathrm{a}$ \\
PPKS 718 & $38.17 \mathrm{a}$ & $39.04 \mathrm{a}$ \\
PPKS 540 & $23.28 \mathrm{a}$ & $43.11 \mathrm{a}$ \\
Dumpy & $(-)$ & 39.37 \\
\hline Interaction & 24.67 & $(-)$ \\
\hline CV $(\%)$ & There is no interaction between the factors tested. \\
\hline Remarks: The means in one column followed by the same letter were not significantly different &
\end{tabular}

Table 5. Plant reponses to $\mathrm{Cu}$ toxicity on shoot growth (\%)

\begin{tabular}{lcc}
\hline \multirow{2}{*}{ Oil Palm Hybrids } & \multicolumn{2}{c}{$\Delta$ Responses on Shoot Growth (\%) } \\
\cline { 2 - 3 } Yangambi & $40.399 \mathrm{a}$ & Total Leaf \\
Avros & $-3.370 \mathrm{~b}$ & $6.349 \mathrm{a}$ \\
Langkat & $50.009 \mathrm{a}$ & $6.435 \mathrm{a}$ \\
PPKS 239 & $53.899 \mathrm{a}$ & $18.238 \mathrm{a}$ \\
Simalungun & $39.632 \mathrm{a}$ & $7.773 \mathrm{a}$ \\
PPKS 718 & $48.846 \mathrm{a}$ & $12.081 \mathrm{a}$ \\
PPKS 540 & $51.574 \mathrm{a}$ & $18.446 \mathrm{a}$ \\
Dumpy & $46.826 \mathrm{a}$ & $16.173 \mathrm{a}$ \\
\hline Average & 40.98 & $13.127 \mathrm{a}$ \\
\hline CV $(\%)$ & 13.418 & 23.365 \\
\hline Remarks: The means in one column followed by the same letter were not significantly different
\end{tabular}

(Nair and Chung, 2014). Increasing lignification could happen because there were at least two $\mathrm{Cu}$ enzymes in lignin biosynthesis: polyphenol oxidase catalysed the oxidation of phenolics as precursor of lignin, and diamine oxidase provided the $\mathrm{H}_{2} \mathrm{O}_{2}$ required for oxidation by peroxidases (Broadley et al., 2012).

The $\Delta$ responses of total root length, surface area, diameter, and volume of Yangabi (P1), Avros (P2), Langkat (P3), PPKS 239 (P4) Simalungun (P5), PPKS 718 (P6), PPKS 540 (P7), and Dumpy (P8) were shown on Table 3 . The hybrids showed different response on root diameter, where Avros hybrid had a greater declining in root diameter. On the other hand, Dumpy hybrid seemed to develop a bigger diameter than other hybrids. Meanwhile, there was no significant difference in root length, area, volume, and fractal dimension.

In excessive $\mathrm{Cu}$, all oil palm hybrids developed their root formation pattern as their fractal dimension increased. Yangambi, Langkat, and PPKS 239 showed the same response in root growth inhibition with decreased root length, surface area, diameter and volume. Avros and PPKS 718 developed more on root length and surface area despite their decreased root diameter and volume. Simalungun and PPKS 540 developed root length despite suffered from inhibition on root surface area, diameter, and volume. Dumpy developed root diameter despite the inhibition of other root growth parameters.

According to Sheldon and Menzies (2004) research 
on $\mathrm{Cu}$ toxicity effect on Rode grass as a bioaccumulator for ex-mining land rehabilitation, $\mathrm{Cu}$ stress led to an inhibition in root growth with several symptoms, such as deformation of root tissue, root cuticle damage, degradating root hair to root structural deformation. The degradating root growth showed at $\mathrm{Cu}$ consentration less than $1 \mu \mathrm{M}$ with invicible damage at $0.2 \mu \mathrm{M}$.

Copper stress induced the synthesis of oxylipins through enzymatic mechanisms (Ritter et al., 2008), which then led to root waving, loss of apical dominance, and a decrease in root elongation (Vellosillo et al., 2007). These actions inhibited root cell growth, such as cell propagation and differentiation, then the accumulation of this reaction was decreasing the root area and length growth, with increased root diameter as a result of lignification in some cell as the increasing of $\mathrm{Cu}$ level. This was one of plant defense mechanism against $\mathrm{Cu}$ toxicity.

There was no significantly different responses on all parameters of biomass (Table 4). Plant with $\mathrm{Cu}$ stress significantly inhibited their biomass translocation to shoot and root for growth in all of palm oil hybrids in this research. In excessive $\mathrm{Cu}$ condition, Zea mays (Mocquot et al., 1996) and Lupinus termis (Gadallah and El-Enany, 1999) also gave the same responses as declining metabolisms and physiological reaction on plant led to dry biomass degradation.

$\mathrm{Cu}$ was important in many physiological processes on plants, such as photosynthesis and respiration. The thylakoid membrane in the chloroplast, especially photosystem II (PSII) was a primary target of $\mathrm{Cu}$ toxicity (Bernal et al., 2004). The elevating of ROS on thylakoid membrane led to an ultrastructural damage in chlorophyll and caused inhibition on photosynthesis by decreasing the clorophyll content on leaf. The damage of membrane and chlorophyll in leaf was shown with necrotic area in leaf at high level of $\mathrm{Cu}$ toxicity, with yellowing interveinal chlorosis in the early stage of $\mathrm{Cu}$ toxicity. It led to a decline in biomass productions as the result of photosynthesis.

Declining in biomass production on plants as the photosynthesis decreased led to a declining in shoot growth. We could observe it from plant height and total leaves per plant which were reduced compared with the control treatment.

In almost all hybrids, $\mathrm{Cu}$ stress inhibited shoot growth, such as plant height and total leaves, except in Avros hybrids (Table 5). In excessive $\mathrm{Cu}$ condition, Avros was able to maintain its shoot growth, including plant height and total leaves per plant. When others hybrids' shoot growth decreased in high $\mathrm{Cu}$ level toxicity, Avros had better shoot growth.

The inhibition of root growth had a bad impact to shoot growth. Root damage reduced its ability on absorption nutrition from media, thus the translocation from root to shoot was reduced as the $\mathrm{Cu}$ level on root increased. These had significantly affected all metabolisms and physiological reactions in shoot, such as photosynthesis and respiration. It was obviously seen in the decreasing of plant height and total leaves per plant of oil palm exposed to excessive $\mathrm{Cu}$. Typically, plants which were given excessive $\mathrm{Cu}$ had an increased $\mathrm{Cu}$ content in their roots. Several studies reported that excessive $\mathrm{Cu}$ did not reach shoot, at least in the first days of $\mathrm{Cu}$ exposure (Navari-Izzo et al., 2006).

\section{CONCLUSION}

$\mathrm{Cu}$ stress in oil palm inhibit the root growth, such as declining in root length, volume, and biomass. The declining in root growth, such as root length, area, diameter, volume, and fractal dimension, led to an inhibition in shoot growth, such as plant height, leaves, and plant biomass.

\section{ACKNOWLEDGEMENT}

This work was founded by the DIKTI Kementrian Riset Teknologi dan Pendidikan Tinggi Republik Indonesia.

\section{REFERENCES}

Ambrosini, V. G., D. J. Rosa, J. P. C. Prado, M. Borghezan, G. W. B. de Melo, C. R. F. de Sousa, J. J. Comin, D. G. Simao, and G. B Runetto. 2015. Reduction of Copper Phytotoxicity by Liming: A Study of The Root Anatomy of Young Vines (Vitis labrusca L.). Plant Physiology and Biochemistry, 96: 270-280.

Andrade, S. A. L., P. L. Gratjo, R. A. Azevedo, A. P. D. Silveira, M. A. Schiavinato, and P. Mazzafera. 2010. Biochemical and Physiological Changes in Jack Bean under Mychorrhizal Symbiosis Growing in Soil with Increasing $\mathrm{Cu}$ Concentrations. Environment Experiment Botany, 68: 18-207.

Bernal, M., Roncel, M., Ortega, J. M., Picorel, R., and Yruela, I. 2004. Copper Effect on Cytochrome b559 of Photosystem II under Photoinhibitory Conditions. Physiol. Plant., 120: 686-694.

Broadley, M., P. Brown, I. Cakmak, Z. Rengel, and F. Zhao. 2012. Function of Nutrients : Micronutrients. In: P. Marschner, ed., Mineral Nutrition of Higher Plants, 3rd ed. Oxford: Academic 
Press, pp. 191-248.

Chen, P. Y., Y. I. Lee, B. C. Chen, and K. W. Juang. 2013. Effects of Calcium Oxalate on Rhizotoxicity and The Accumulation and Translocation of Copper Grapevines. Plant Physiology Biochemistry, 73: 375-382.

Clemens, S. 2001. Molecular Mechanisms of Plant Metal Tolerance and Homeostasis. Planta, 212: $475-486$.

De Vos, C. H. R., H. Schat, M. A. M. De Waal, R. Vooijs, and W. H. O. Ernst. 1991. Increased Resistance to Copper-Induced Damage of Root Cell Plasmalemma in Copper Tolerance Silene cucubalus. Physiol Plant, 82: 523-528.

Del Rio, L. A., L. M Sandalio, F. J. Corpas, J. M. Palma, and J. B. Barosa. 2006. Reactive Oxygen Species and Reactive Nitrogen Species in Peroxisomes: Production, Scavenging and Role in Cell Signaling. Physiology Plant, 141 : 330-335.

Fidalgo, F., M. Azenha, A. F. Silva, A. de Sousa, A. Santiago, P. Ferraz, and J. Teixeira. 2013. Copper-Induced Stress in Solanum nigrum L. and Antioxidant Defense System Responses. Food and Energy Security, 2(1): 70-80.

Gadallah, M. A. A., and A. E. El-Enany. 1999. Role of Kinetin in Alleviation of Copper and Zinc Toxicity in Lupinus termis Plants. Plant Growth Regulation, 29: 151-160.

Gardner, F. P., Pearce, R. B. and Mitchell, R. L. 1985. Physiology of crop plants. The IOWA State: University Press.

Juang, K. W., Y. I. Lee, H. Y. Lai, and B. O. Chen. 2014. Influence of Magnesium on Copper Phytotoxicity to and Accumulation and Translocation in Gapevines. Ecotoxicology Environmental Safe, 104: 36-42.

Kabala, K., M. Janicka-Russak, M. Burzynski, and G. Klobus. 2008. Comparisson of Heavy Metal Effect on The Proton Pumps of Plasma Membrane and Tonoplast in Cucumber Root Cells. Journal Plant Physiology, 165: 278288.

Lequeux, H., C. Lutts, and N. Verbruggen. 2010. Response to Copper Excess in Arabidopsis Thaliana: Impact on The Root System Architecture, Hormone Distribution, Lignin Accumulation, and Mineral Profile. Plant Physiology Biochemistry, 48: 673-682.

Lin, C. C., L. M. Chen and Z. H. Liu. 2005. Rapid Effect of Copper on Lignin Biosynthesis in Soybean Roots. Plant Science, 168: 855-861.

Marschner, H. 1995. Mineral nutrition of higher plants. 2nd ed. London: Academic Press.

Miotto, A., C. A. Cereta, G. Bruneto, F. T. Nicoloso, E. Giroto, and J. G. Farias. 2014. Copper Uptake:
Accumulation and Physiological Changes in Adult Grapevines in Responses to Excess Copper in Soil. Plant Soil, 374: 593-610.

Mocquot, B., J. Vangronsveld, H. Clijsters, and M. Mench. 1996. Copper Toxicity in Young Maize (Zea mays L.) Plants: Effect on Growth, Mineral and Chlorophyll Contents and Enzyme Activities. Plant and Soil, 182: 287-300.

Nair, P. G. and I. Chung. 2014. A Mechanistic Study on The Toxic Effect of Copper Oxide Nanoparticles in Soybean (Glycine max L.) Root Development and Lignification of Root Cells. Biol Trace Element Res, 162: 342-352. Navari-Izzo, F., B. Gestone, A. Cavallini, L. Natali, T. Giordani, and M. F. Quartacci. 2006. Copper Excess Triggers Phospholipase D Activity in Wheat Roots. Phytochemistry, 67: 12321242.

Pilon, M., S. E. Abdel-Ghany, C. M. Cohu, K. A. Gogolin, and H. Ye. 2006. Copper Cofactor Delivery in Plant Cells. Curr Opin Plant Biology, 9: 256-263

Ritter, A., S. Goulitquer, J. P. Salaun, T. Tonon, J. A. Correa, and P. Potin. 2008. Copper Stress Induces Biosynthesis of Octadecanoid and Eicosanoid Oxygenated Derivative in The Brown Agal Kelp Laminaria digitata. New Phytol, 180: 809-821.

Sheldon, A. and N. W. Menzies. 2004. The Effect of Copper Toxicity on The Growth of Rhodes Grass (Chloris gayana) in Solution Culture. Paper presented to SuperSoil 3rd Australian New Zealand Soils Conference, University of Sydney, Australia, 5-9 December.

Vellosillo, T., M. Martinez, M. A. Lopez, J. Vicente, T. Cascon, L. Dolan, M. Hamberg and C. Castresana. 2007. Oxylipins Produced by The 9-lypoxygenase Pathway in Arabidopsis Regulate Lateral Root Development and Defense Response Through A Specific Signaling Cascade. Plant Cell, 19: 831-846.

Yruela, I. 2005. Copper in Plants. Braz. J. Plant. Physiol, 17(1): 145-156.

Yruela, I. 2009. Copper in Plants: Acquisition, Transport and Interactions. Funct Plant Biol., 36: 409-430. 